\title{
The expert
}

Cite as: CMAJ 2017 August 8;189:E1019-20. doi: 10.1503/cmaj.161369

CMAJ Podcasts: article reading at https://soundcloud.com/cmajpodcasts/161369-enc

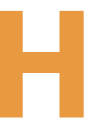

e was clearly from another time.

The way he lowered his head when greeted, or how he insisted on courteously kissing the ladies' hands - he was the quintessential gentleman. He leaned in closely to listen when spoken to and would studiously repeat your name after being introduced. He gripped his hands tightly over yours as he spoke, profusely expressing his gratitude for your kind visit.

"I have cancer" are his first words to us; we nod silently. This is curious when you consider the endless variety of phrases a person can choose from to introduce himself or herself, to define himself or herself. Most would proudly brand themselves with their occupation or titles, or perhaps speak at length regarding their roles as parent, spouse or friend. Whether this was the product of his insight into his current surroundings or an obsessive fixation on his transformative diagnosis, I will never know. Unprompted, he relays to us the metastatic spread, his dysphagic symptoms and the perpetual gnawing pain in his abdomen. When asked how he is doing, he responds evenly, "I am dying." Again, we nod, for there are no words to say.

We excuse ourselves, retreating behind the glass windows, and the nurse slowly recounts the details before admission.

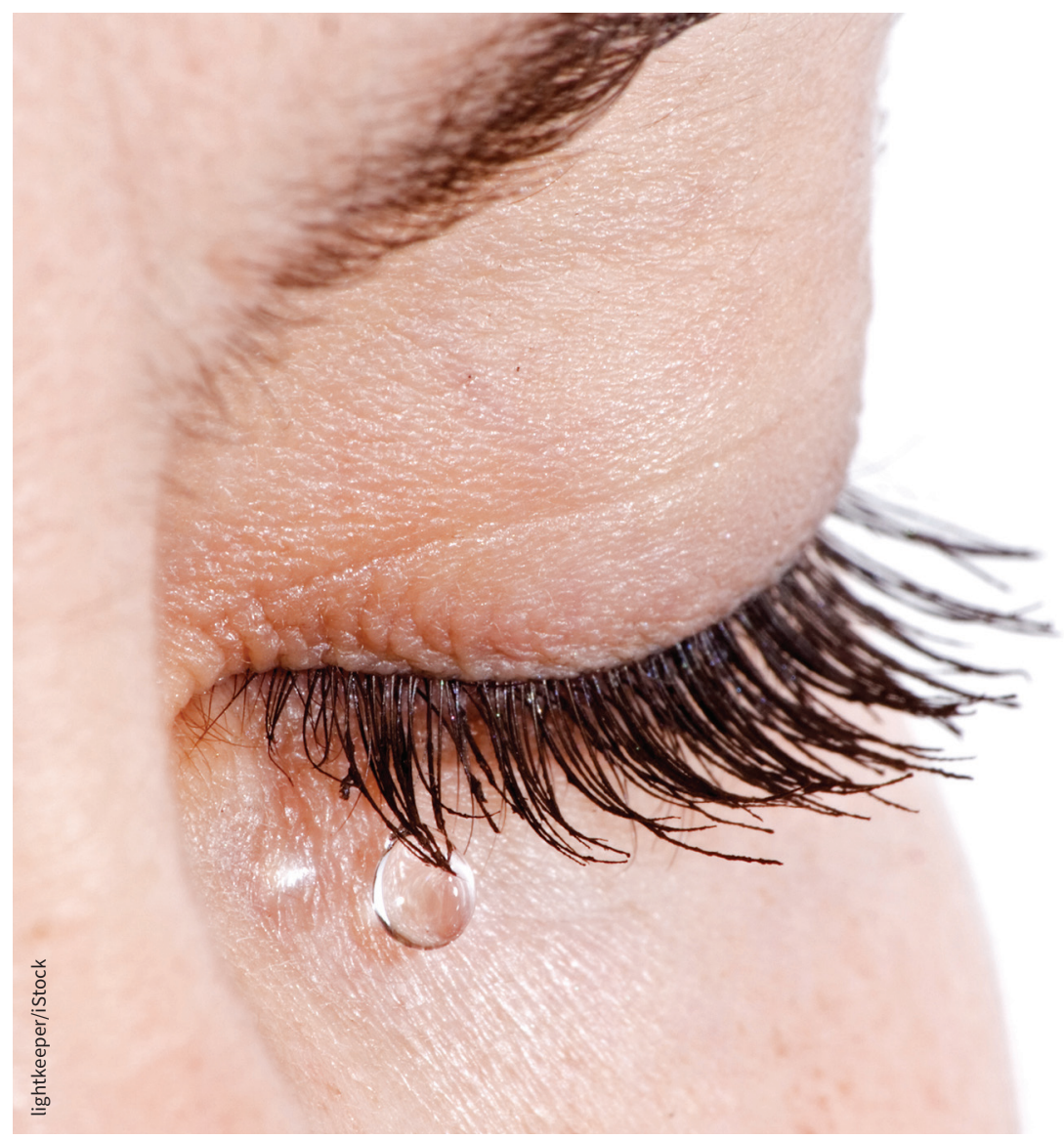

"Escalating episodes of inconsolable agitation, unabated insomnia, repeated outbursts and, at one point, Mr. Marchand waved a kitchen knife threateningly at his own daughter." The concerned physician scrupulously examines the patient's list of medications and swiftly scribbles an asneeded dose of lorazepam to add to the list. We glance over at the frail patient now reclining uncomfortably in his hospital bed. The intensive care unit is no place for a dying man.

Death is curious: a rite of passage we all must undergo, its universality is matched only by its terrifying inscrutability. It is a shared experience none have returned to share. Consequently, physicians are limited in our capacity to empathize. When confronted with death, each of us may choose to process the unknown differently. There are those, though, who appear to gain some comfort in relinquishing the desire to understand death and its mysteries, attaining solace instead in its full embrace.

We buzz past the locked doors into the secluded unit the following day. With our notebooks in hand, we speak with him with the aim of further psychiatric evaluation. His mood is level, his appetite is adequate and his sleep is uninterrupted. We ask if he hears voices in his head; he calmly affirms. The physician furrows her brow and inspects him carefully. "What kind of voice is it?" she asks. "It is the voice of God." Her expression softens slightly. "And what does He say to you?" "He tells me to behave myself!" he replies matter of factly. As we chuckle, he abruptly falls onto his knees by the bedside, clasps his hands together and starts to pray. We wait patiently for him to finish as he mouths wordlessly. Opening his eyes, the doctor leans over to ask if he finds comfort in prayer. He nods heartily. "I'm glad," she says, smiling warmly. 
It is commonly acknowledged, although not widely appreciated, how much physicians can learn from patients. Although we have gradually shifted away from the paternalistic approach of yesteryear, in many respects physicians still retain a position of authority. We are the ones who possess the medical knowledge, who write the hospital orders for diagnostic investigations, and who discern the appropriate use of prescription drugs. But who is the expert here: the ones who have postulated and researched death from afar or the man who openly confronts it in spite of his infirmity?

He has barely eaten in two days and has only just settled after an exhausting night of distressing wails and exit-seeking behaviour. "Mr. Marchand, are you in pain?" He croaks inaudibly, and we struggle to understand. The palliative care service had been con- sulted and assured us his pain medications were optimally adjusted.

As the days progress, his English appears to regress gradually along with his declining condition. The psychiatrist stoops by his bed and asks him gently, "As-tu peur, M. Marchand?" He looks up with glassy eyes and a distant look, and softly whispers, "Un petit peu."

We head downstairs to meet with the family and discuss options. In a quiet corner, the doctor delicately provides her medical assessment. "We were originally hoping to transfer him closer to home, but your local hospital informed us the next available bed will take weeks. At this point, we are unsure if Mr. Marchand has time as a luxury. We will respect your decision, but there is a spot at our palliative care unit today ... ." Mr. Marchand's wife nods understandingly while sobbing. "We want him to be comfortable. We just didn't know it would come so soon." The physician pauses briefly and responds with the faintest quiver in her voice, "Our thoughts are with you and your family." She stands up and begins walking briskly down the hall. As I attempted to keep pace, I could have sworn she furtively wiped away a tear.

\section{Shannon Chun HBSC}

MD candidate, Class of 2017, School of

Medicine, Queen's University, Kingston, Ont.

This article has been peer reviewed.

This is a true story. The family has given permission for it to be told, and the name has been changed.

This story received an honourable mention for the Annual Undergraduate Narrative Award for Palliative Care from the Canadian Society of Palliative Care Physicians. 